\title{
Political and Legal Factors' Influence in Motivating Pro-ecological Behaviour of the Firm: The Case of the Queen Monaco Company (Romania)
}

\author{
Laura Wahed* and Rodica Milena Zaharia* \\ ${ }^{\star} \mathrm{PhD}$, Bucharest University of Economic Studies, \\ Department of International Business and Economics, CCREI
}

\section{Introduction}

The importance of political and legal factors in orienting firms towards a proecological behaviour is crucial. It is a truism that in countries that promote the pro-ecological legislation and where the application of the law is consistent, the companies are encouraged to promote actions that imply a pro-ecological vision towards their businesses. Also, when political and legal factors are in consonance, companies transform their behaviour from a reactive one (to adapt to the law) to a proactive one (to anticipate the environmental legislation trends and to find out how upcoming legislation can affect the business).

The legal context represents the central system that shapes competition, orients the companies' actions towards employers, regulates the relationships between companies and public authorities or determines the balance of power between the customers and the company. The political factors are those that implement the legal system and may disrupt or accelerate the implementation

How to cite this book chapter:

Wahed, L. and Zaharia, R. M. 2019. Political and Legal Factors' Influence in Motivating Pro-ecological Behaviour of the Firm: The Case of the Queen Monaco Company (Romania). In: Gąsior, A. (ed.) Pro-ecological Restructuring of Companies: Case Studies, Pp. 5-14. London: Ubiquity Press. DOI: https://doi.org/10.5334/bbk.b. License: CC-BY 4.0 
of the legal framework. Political factors may also change the legal context and control how laws and regulations are respected. Mostly in the area of environmental protection, the legal and political factors are essential.

Political and legal factors are, probably, among the least predictable factors that influence businesses. Pressure groups tend to change government policies, and these policies may diverge in different directions, according to the power of the interest group. In some cases, consumers are the winners; in others, businesses manage to enact their visions. Political and legal factors also influence the quality of the competition. Some firms survive and grow by offering bribes to government officials. The success and growth of these companies are not based on their competitiveness, and the consumers are prevented from having fair access to the most competitive products. Sometimes, the safety of the consumers is affected, when the legal and political factors do not follow the principles of correctness, law enforcement, equal opportunities and fair competition.

\section{Objectives and Methodology}

The case study analysed in this section shows how political and legal factors are embedded in a company's strategy and how they influence the company's behaviour. It explains a reactive behaviour, as a consequence of unpredictability of legal framework and political actions. The research method used here is the case study, a qualitative method that underlines the importance of the context when a specific situation is analysed. Case study research allows the exploration and understanding of complex issues, mostly when a holistic, in-depth investigation is required (Zainal 2007). Yin (1984:23) defines the case study research method "as an empirical inquiry that investigates a contemporary phenomenon within its real-life context; when the boundaries between phenomenon and context are not clearly evident; and in which multiple sources of evidence are used."

The appropriateness of a case study methodology for this situation is determined by the importance of the context over the pro-ecological behaviour of the company. Environment is a very delicate subject. Many times, issues related to environmental protection are placed in antagonist positions with issues related to economic development. This view expresses mostly the priorities of developing and less developed countries, according to which feeding and sheltering people is more urgent than protecting the environment. Even at the level of the EU there are differences between Northern Europe, much more concerned with environmental protection, and countries from the South or former socialist states where environmental protection, both at the level of framing legislation and implementation of the law, are weaker. The environmental policy in the EU "rests on the principles of precaution, prevention and rectifying pollution at source, and on the 'polluter pays' principle" (European Parliament 
2016). In the absence of a strong institutional frame, and a clear legislation related to environmental protection, the reactive behaviour of the companies towards a pro-ecological attitude is encouraged. Also, the fact that a common legislation regarding the environment in the EU does not exist, that there are double standards related to environmental protection, induces some difficulties in implementing strong environmental policies across Europe and explains differences among countries in the performances related to environment quality and consumer protection.

\section{Romanian Context: How Legal, Institutional and Political Factors Influence the Behaviour of Companies in the Area of Environmental Protection}

Romania, as a member of the EU since 2007, constantly improved its legislation in the area of environmental protection. The current regulations are based on several legal principles, as in the case of other EU member states, such as: (i) compliance with the environmental acquis communitaire; (ii) integration of environmental concerns into sectoral policies; (iii) monitoring and reduction of climate change risks; (iv) application of the "polluter pays" principle; (v) preservation of biodiversity and specific ecosystems; (vi) sustainable use of natural resources; (vii) disclosure of environmental information and public participation in decision-making; and (viii) international cooperation for environmental protection (UNECE 2012).

There are three main authorities having competencies in the environmental protection field, each covering a specific activity area (KPM 2016, p.127):

The Ministry of Environment, Water and Forest (MEWF) is the central environmental authority, having environmental legal framework, policymaking and strategy development. The MEWF also acts as liaison with the European Commission for fulfilling Romania's reporting obligations under various EU directives.

The National Environmental Protection Agency (NEPA) is the central implementation authority and ensures the necessary training process for all parties involved in environmental matters. It is mainly in charge of the coordination of various permitting procedures through its regional and local agencies (43: one for each county, one for Bucharest, and a special authority for the Danube Delta).

The National Environmental Guard (NEG) is the main enforcement authority, having competences mainly in respect of verifying compliance with applicable environmental regulations and norms by companies. The NEG is represented by a Local Environmental Guard (LEG) in each county and in Bucharest. For noncompliance, LEGs impose penalties, according to the amount of environmental damage or risk caused by the non-compliance. 
However, the National Environmental Protection Agency (NEPA) and the National Environmental Guard (NEG) do not have a joint database that would facilitate information-sharing on both the technical characteristics of regulated entities and their most recent compliance behaviour and enforcement actions taken against them (UNECE 2012).

Despite many improvements in enforcing a strong legislation and imposing strong norms towards environmental protection, environmental problems persist in Romania. A variety of illegal forestry and resource activities persist, stemming from corruption and weak oversight on behalf of the government. In spite of the actions taken by the Ministry of Environment, Waters and Forestry, the country faces significant challenges in managing its relations with large multinational corporations that seek to operate under the weakly regulated environmental regime. Increased taxation on landfill waste and penalties imposed by the National Environment Guard has marginally contributed to improving the environmental situation, but also yields corruption concerns (Sustainable Governance Indicators 2016).

There are many areas of environmental protection where Romania has a critical position. One of them is the recycling process. Romania is among the last EU countries in terms of recycling waste. Romania should reach $50 \%$ of waste recycling in 2020, otherwise, according to the treaties Romania has signed, the infringement procedure will be applied and penalties of 200,000 euro per day will be paid. Also, the legislation in the area of waste recycling was updated with the European directive only at the last moment. The new Emergency Government Ordinance 68/2016 transposes into the national legislation the provisions of Directive 2008/98/EC of the European Parliament and Council dated November 19th, 2008, regarding the waste and repeals certain directives. Among many provisions of the new legal act, the EGO 68/2016 imposes on waste producers and holders the obligation to separately collect all waste categories in the event that such is technically, economically appropriate and environmentally safe. At the same time, the obligation for such materials not to be mixed with other waste or materials with different features is expressly stipulated (Pachiu \& Associates 2016). Also, for keeping track of waste management, the EGO 68/2016 mentions that producers of non-hazardous waste, units and undertakings conducting waste treatment activities, hazardous waste producers, economic operators authorized for collecting and carrying hazardous waste or acting as waste sellers or brokers have the obligation to ensure chronologic record of waste management for each type of waste, as well as of the amount, nature and origin of waste and, as applicable, of the destination, frequency of collection, means of transportation and treatment, capitalization or removal of waste according to the provisions of the 2014/955/EU Commission Decision and make it available to the competent control authorities, upon the request of these entities (Pachiu \& Associates 2016).

The Ministry of Environment, Water and Forest discovered that many companies actively recycling waste broke the law and reported higher values of 
recycled wasted than they had done in reality. DIICOT descended on 59 companies and individuals suspected to have produced a difference of 54 million euro (Zaharia 2016). The authorities imposed fines and asked for real reports until the end of January 2016. According to law no. 24/ 2015, any company that delivers market-packaged goods has to recover packaging waste resulting from consumption. The law applies to any EU country, not only in Romania. To comply with this responsibility, businesses can organize themselves in associative structures called responsibility transfer organizations or may recover waste placed on the market through its own resources. If operators do not fulfil the assumed targets, they are legally required to contribute to the Environment Fund with 2 lei per kilogram of non-recycled packaging (packing tax).

Large protests were organized at the beginning of 2016 against this penalty and many companies, producers and retailers associations asked for fiscal amnesty for 2015 and for the reduction of the tax for the future. They threat the authorities with street protests, claiming that this tax will lead to insolvency for many producers and large unemployment in the food industry (Zaharia 2016). They also claimed that the ministry was not able to establish a functional system of recycling waste packages and these penalties should punish the government for incompetency, not the producers and retailers. After many discussions between the Ministry and the representatives of larger retailers and producers, the "packing tax" a new law was proposed in the parliament, to reduce this tax from 2 lei per kilogram to 0.30 lei per kilogram (Breniuc 2016). Despite the opposition coming from environmental NGOs, even against the opposition expressed by the Ministry of Environment, Water and Forest, the politicians gave in to the pressures of the different business interests groups and moved the law forward for approval. By the beginning of November 2016, the law had passed the Senate. There will be further discussion in the Chamber of Deputies, which is the last approval forum.

This demonstrates how politicians may change the law at the pressure of different interest groups. When the politicians can be forced to postpone the enforcement of the law, this raises suspicions about incompetency or corruption, creates unfair competition, does not motivate companies to be proactive towards environmental protection and does not educate consumers in demanding pro-ecological behaviour. Also, these changes do not induce predictability from the point of legislative stability. This lack of predictability could stand as an explanation for the reluctance of some Romanian economic agents to show proactive behaviour towards environmental protection.

Within this context, most companies have a reactive attitude towards environmental protection. The case study analysed here demonstrates reactive behaviour towards the legislation, inducing the idea that companies use precaution in investing in a pro-ecological action. This precaution may be explained by the fact that the only pressures the companies face derive from the legislation. Company's competitiveness is not positively influenced by the pro-ecological attitude, investments in protecting the environment are not rewarded by society 
and investments in pro-ecological activity are not justified by a predictable evolution of the legislation. The politicians may change the legislation to a less protective law for the environment or may postpone the enforcement of the law, if the pressure from producers and retailers is big enough. Under these circumstances, companies do the minimum in this area, preferring to rest on complying with the law and adopting those measures that are most economically beneficial.

\section{Company Performance and History of Activities}

Set up in 1996, Queen Monaco is an important company in the fast-moving consumable goods (FMCG) market in Romania, having more than 140 employees in several business locations and an annual turnover that increased over time to an estimated $€ 20$ million in 2016, according to the data provided by the management of the company. During the past 20 years, the company evolved and developed gradually from a small local business to a holding that today entails several companies specializing in different business activities such as retail, distribution, logistics, and import-export and business consultancy.

Currently, Queen Monaco has a diversified portfolio of business partners, including multinational companies, such as Lavazza Coffee, Kimbo Coffee, XL Energy Drinks, Philip Morris, La Festa, Imperial Tobacco or Maspex. In addition, Queen Monaco developed business partnerships with the most important Key Accounts on the Romanian market, its most significant partners being Carrefour, Hypermarche Romania (Cora), Auchan, Kaufland, Metro and Selgros, besides the other 6000 traditional retail customers that enrich the customer portfolio.

\section{Protecting the Environment: The Role of Political and Legal Factors in the Environmental Policy of the Company}

As with many other companies, Queen Monaco has a reactive attitude towards environmental protection. From this perspective, the management of the company complies with the regulations and procedures imposed by the governmental institutions, and limits the integration of the pro-ecological principles to the adaptation to the national legislation. However, as some of its commercial partners adopted pro-environmental behaviour, the company has also undertaken some strategies to respond in a positive manner to the environmental pressures and to improve the environmental outcome.

Ecological issues have become an important issue in Romania, and Romania has implemented new laws and regulations that try to reduce the negative impact of business activities on the environment. For example, the new Fiscal 
Code has introduced an additional ECO tax for plastic bags in order to discourage the use of the polluting materials. With operations in the import-export of food products and their distribution on the Romanian retail market, Queen Monaco was directly influenced by this regulation and it had to enforce it by replacing the plastic bags with eco-friendly paper bags. However, not following the legislation would have worse consequences on the company, mainly the penalties, bad publicity and retaliation from (few) business partners who would consider that being associated with somebody who is not concerned about the environment is not good for their image. Besides this regulation, the Marketing Department has shown a constant preoccupation in recent years for the quality of packaging of imported products, requesting the suppliers use non-polluting materials (or the less-polluting ones), with a minimum impact on the environment. Moreover, in agreement with the Romanian law no. 249/2015, which refers to the management of packaging and the waste derived from packaging, the company drew up a contract with a responsibility transfer organization, which takes the responsibility for recycling the packaging delivered by the company. As a consequence of this legislation, the amount of materials recycled by the company has considerably increased in the last year. This reactive, and not proactive, attitude the company adopted towards the legislation responsible for environmental protection is also explained by the costs generated by complying the law. For example, in 2015, as compared to 2014, the tax paid by the company for waste and packaging recycling more than doubled for the same quantity of waste.

As regards the operations of storage of food products, the company complies with the national legislation, which imposes very high standards related to the prevention of food contamination and, therefore, to the avoidance of ecological risks. For this purpose, Queen Monaco made investments in purchasing new environmentally-friendly technologies as well as in training the employees in adopting pro-ecological behaviour in food storage areas. The HACCP (Hazard Analysis Critical Control Point) system was implemented, achieving accreditation ISO 9001- quality management system, the procedures aiming at protecting the environment. The HACCP principles were adopted by the Codex Alimentarius Commission established by Food and Agriculture Organization (FAO) and World Health Organization (WHO) to protect consumer health. From this perspective, the company identifies, evaluates and controls the potential risks that might occur in the process of food product storage and distribution. Moreover, a specialized manager is currently in charge of these environmental procedures, being bound to implement and control all the measures and to encourage the pro-ecological behaviour among the employees. This program also has resource efficiency purposes, that is, the person delegated to perform this process has elaborated an Environmental Management Program (EMP), which includes specific procedures in order to reduce the business impact on the environment: 
- To minimize the use of natural resources, such as fuel, by grouping the merchandise and transporting it towards the customers, avoiding several transports (the company owns 60 vehicles, from small cars to trucks; therefore, the fuel use is significant on a daily basis, especially for the distribution operations).

- To avoid material waste (for example, the pallets received with the imported goods are reused on the internal market, and the cardboard boxes or the plastic thin sheets are reused to package other goods).

- To manage the waste (in the warehouses, as well as in the offices, the waste resulting from commercial activity is carefully collected in separate units, being subsequently delivered to the waste collector for recycling).

- To minimize energy consumption (an intelligent lighting system was introduced, eliminating traditional bulbs).

- To reduce paper use by printing only the important documents, to electronically archive the fiscal documents and to issue electronic bills.

- To encourage employees to actively engage in environmental protection.

The legislative changes and standardized procedures related to the environmental issues imposed measures that created short-term high costs for the company (acquiring innovative technologies, training employees etc.), but in the long run the effects are beneficial, being reflected in cost production and storage cuts as well as in the contribution to a healthier environment.

The company accomplishes the standards imposed by the consumer protection legislation in Romania, that is, it stores and distributes the products in optimal conditions. For this purpose, the warehouse manager is in charge of achieving the standards of storage and transportation with special vehicles (designed for food transportation and authorized for this purpose only) in compliance with the legislation in force as well as the producers' recommendations imprinted on the package or the quality certificates. Moreover, the warehouse manager is responsible with controlling the warehouse temperature and humidity, which should be between minimum $5^{\circ} \mathrm{C}$ and maximum $25^{\circ} \mathrm{C}$ and the relative humidity $\mathrm{RH}$ between a minimum of $25 \%$ and a maximum of $75 \%$, keeping a daily register of all these data.

Another measure that considers consumer protection relates to the employees who handle the merchandise. They have medical tests regularly in order to protect the consumers and to secure a healthy work environment and are continuously trained to improve their performance in adopting pro-environmental behaviour. In addition, each batch of products is tested by authorized laboratories in order to assure the quality standards of the goods.

The warehouses comply with the European standards of hygiene (being periodically controlled by the Sanitary Veterinary and Food Safety Department), having a specially painted floor for keeping a clean environment and doors equipped with filters against dust and insects. Moreover, the company is checked monthly by the same institution that evaluates the sanitary standards 
of food product storage. Regularly, a pest control company is in charge of the warehouse inspection in order to control the pest issues and to maintain a clean environment for consumer protection.

\section{Conclusions}

Political and legal factors are essential in shaping the business environment and in determining the behaviour companies have towards the environment. This case study demonstrates how legal and political factors influence the restructuring policy of a company.

Romania has made much progress in protecting the environment. From a legal point of view, Romania adopted a legislation that is in consensus with the European laws and regulation towards environmental protection. Also, Romania established institutional framework responsible for the laws' enforcement, control and fines for those which do not comply with the law. Not too much has been done in the prevention area, which explains why companies are reactive rather than proactive. Also, politicians proved to be quite sensitive towards the business pressure and interests and didn't promote a strong commitment towards environmental protection.

The case study analysed here demonstrates that companies have a reactive rather than a proactive attitude towards pro-ecological action when environmental protection is seen mostly as a cost, not a competitive advantage. This is possible when legal and political factors are unpredictable.

\section{References}

Breniuc, I 2016 Legea privind reducerea taxei pe ambalaje a trecut de Senat. Available at http://www.green-report.ro/reducerea-taxei-pe-ambalaje-senat: [Last accessed 15 June 2017].

European Parliament 2016 Environment policy: general principles and basic framework. Available at http://www.europarl.europa.eu/atyourservice/en/ displayFtu.html?ftuId=FTU_5.4.1.html: [Last accessed 15 June 2017].

KPMG 2016 Investment in Romania 2016. Available at https://assets.kpmg. com/content/dam/kpmg/pdf/2016/04/ro-investment-in-romania-2016. pdf: [Last accessed 18 June 2017].

Pachiu \& Associates 2016 Legal Update ENVIRONMENT. Available at http:// www.pachiu.com/wp-content/uploads/2016/10/Legal-Update_Environ ment_EN.pdf: [Last accessed 20 June 2017].

Stan, L \& Zaharia, R 2016 Romania. European Journal of Political Research Political Data Yearbook 2015, Vol. 55, No. 1, pp. 224-230. DOI: https://doi. org/10.1111/2047-8852.12152 
Sustainable Governance Indicators 2016 Romania. Available at http://www. sgi-network.org/2016/Romania/Environmental_Policies: [Last accessed 20 June 2017].

UNECE 2012 Environmental Performance Reviews. Romania. Available at http://www.unece.org/fileadmin/DAM/env/epr/epr_studies/Romania_ II.pdf: [Last accessed 10 July 2017].

Yin, R K 1984 Case Study Research: Design and Methods. Beverly Hills, Calif: Sage Publications.

Zaharia, C 2016 Taxa pe ambalaj scoate oamenii în stradă. Industria alimentară va picheta sediul Ministerului Mediului. Available at http://www.greenreport.ro/taxa-pe-ambalaj-scoate-oamenii-in-strada-industria-alimentarava-picheta-sediul-ministerului-mediului/: [Last accessed 20 June 2017].

Zainal, Z 2007 Case study as a research method. Jurnal Kemanusiaan bil.9. Available at http://eprints.utm.my/8221/3/ZaidahZainal2007_CaseStudy asaResearchMethod.pdf: [Last accessed 20 June 2017]. 